\title{
Determinants of Differentiation of Cost of Risk (CoR) among Polish Banks during COVID-19 Pandemic
}

\author{
Zbigniew Korzeb ${ }^{1, * \mathbb{D}}$ and Paweł Niedziółka ${ }^{2}$ (D) \\ 1 Department of Management, Economy and Finance, Bialystok University of Technology, \\ 15-351 Białystok, Poland \\ 2 Banking Institute, Warsaw School of Economics, 02-554 Warszawa, Poland; pniedz@sgh.waw.pl \\ * Correspondence: z.korzeb@pb.edu.pl
}

Citation: Korzeb, Zbigniew, and

Paweł Niedziółka. 2021.

Determinants of Differentiation of Cost of Risk (CoR) among Polish Banks during COVID-19 Pandemic Journal of Risk and Financial

Management 14: 110

https://doi.org/10.3390/

jrfm14030110

Academic Editors:

Irena Jindřichovská,

Anna Białek-Jaworska,

Mihaela Mocanu and

Erginbay Uğurlu

Received: 3 February 2021

Accepted: 3 March 2021

Published: 8 March 2021

Publisher's Note: MDPI stays neutral with regard to jurisdictional claims in published maps and institutional affiliations.

Copyright: (c) 2021 by the authors. Licensee MDPI, Basel, Switzerland. This article is an open access article distributed under the terms and conditions of the Creative Commons Attribution (CC BY) license (https:// creativecommons.org/licenses/by/ $4.0 /)$.

\begin{abstract}
The aim of the paper is to assess the evolution of the cost of credit risk (CoR) of Polish banks as a result of the COVID-19 pandemic in the first three quarters of 2020 as well as its microeconomic determinants. We analysed the structural diversity of the sample of the 13 largest Polish commercial banks in terms of the evolution of their CoR. For this purpose, a diagraphic method of Jan Czekanowski was used. It allowed us to distinguish two groups of banks displaying features characteristic of multi-object structures and three groups consisting of individual banks characterized by atypical CoR developments, significantly different from the structures of objects classified to the first and second groups. In the second part of the research, in order to identify the determinants of the observed trends, a multiple regression model was used in which the explanatory variable was the dynamics of CoR in the first three quarters of 2020. The parameters of return on capital (ROE) at the end of 2019, Non-Performing Loans (NPLs) at the end of 2019 and the dynamics of write-offs in the period 2017-2019 proved to be important explanatory variables.
\end{abstract}

Keywords: COVID-19; cost of risk; non-performing loans; Polish banking sector

\section{Introduction}

COVID-19 has been the largest pandemic since the Spanish flu, which occurred in the second decade of the 20th century. Despite a range of measures taken by the European Union, governments, international institutions and central banks to support individuals, businesses and financial institutions, the economic impact of the pandemic cannot yet be determined.

The aim of the paper is to assess the evolution of the cost of credit risk (CoR) of commercial banks in the Polish banking sector as a result of the COVID-19 pandemic in the first three quarters of 2020 as well as its microeconomic determinants.

The study was based on the consolidated financial results of Polish commercial banks listed on the Warsaw Stock Exchange for the period from the end of 2019 to 30 September 2020. Taking into account the criterion of the balance sheet total, these banks together represent approx. $85 \%$ of the Polish banking sector, and the share of the largest bank not covered by the survey does not exceed $2 \%$. To the authors' knowledge, this is the first analysis of the microeconomic determinants of the cost of risk based on pandemic data and one of the few studies that focuses on identifying characteristics of banks with outlier cost-of-risk dynamics compared to the sample average. The paper also formulates a question about the determinants of the cost-of-risk dynamics.

In the article, the structural diversity of the sample of the 13 largest Polish commercial banks was analysed in terms of the evolution of its CoR. For this purpose, a diagraphic method of Jan Czekanowski was used. It allowed distinguishing two groups of banks displaying features characteristic of multi-object structures and three groups consisting of individual banks characterized by atypical CoR developments, significantly different from the structures of objects classified to the first and second group. In the second part 
of the research, in order to identify the determinants of the observed trends, a multiple regression model was used in which the explanatory variable was the dynamics of CoR in the first three quarters of 2020. The parameters of return on capital (ROE) at the end of 2019, Non-Performing Loans (NPLs) at the end of 2019 and the dynamics of write-offs in the period 2017-2019 proved to be important explanatory variables.

The remainder of this article is structured as follows: Section 2 is dedicated to the review of the related literature, Section 3 describes the data and methodology employed in the empirical research, Section 4 presents the results, Section 5 is the discussion, and Section 6 contains a summary and presents key conclusions.

\section{Literature Review}

Naili and Lahrichi (2020) reviewed 69 studies dedicated to NPLs published between 1987 and 2019 in 40 peer-reviewed journals. This allowed them to conclude that despite the extensive empirical and theoretical studies on different aspects of credit risk management, it still remains an unsolved line of inquiry with ample room for critical debates.

The banking sector before the pandemic crisis was characterised by a high level of regulatory capital and liquidity as well as by the relatively good quality of credit portfolios. Consequently, Bitar and Tarazi (2020) concluded that on the eve of the pandemic G-SIBs banks had been adequately capitalized. The researchers analysed the effects of prudential regulatory intervention to soften the approach to non-performing loans and ease capital buffers on these banks and the economy. In their opinion, the above measures shall not undermine banks' solvency. It seems that for the first time banks are not the source of the crisis, but the banking sector is seen as having the potential to absorb the shock (Borio 2020), despite the fact that the sector is particularly vulnerable to the COVID-19 pandemic. Demirguc-Kunt et al. (2020) indicate that bank stocks were undervalued compared to other sectors of the economy during the pandemic. This, in turn, can be seen as investors' expectation that banks will experience a deeper reduction in earnings than other sectors of the economy and other types of financial entities. In many studies, the attention of researchers has been focused on the channels of the impact of the pandemic crisis on the banking sector and its ability to support the real economy in terms of providing it with sufficient liquidity. Kulinska-Sadłocha et al. (2020) examined the direct and indirect consequences of the COVID-19 pandemic on the Polish banking sector. According to these authors, the anti-crisis measures of the government, the central bank and the supervisory authorities were reflected in the financial situation of banks already in the first month of their introduction, among others through increased write-offs on receivables. For this reason, banks have tightened their lending policies and focused mainly on financing their existing customers with only temporary financial problems caused by COVID-19. Korzeb and Niedziółka (2020) showed that one of the most important factors affecting banks' resilience to the COVID-19 crisis is the branch structure of their loan portfolios. Cecchetti and Schoenholtz (2020) referred to the Global Financial Crisis and found that providing liquidity to banks in a period of fierce deposit withdrawals is crucial in managing a pandemic crisis. The significant increase in bank liquidity risk during the first phase of the COVID-19 crisis was also pointed out by Li et al. (2020). These authors noted that in March 2020 banks faced the largest growth of liquidity demands ever observed due to the fact that institutional clients drew funds on a massive scale. In turn, the need for simultaneous and separate analysis of the impact of the pandemic crisis on banks in the short and long term as well as in the systemic dimension is indicated by Wu and Olson (2020). Thus, contrary to the widely expressed fears, there was no credit crunch and no slowdown in lending triggered by supply reasons, and its moderate dynamics should rather be attributed to demand factors. These in turn stem from uncertainties about how the pandemic will unfold, how long it will last, how it will change stakeholders' business and consumption patterns. Lower-than-expected demand for bank credit is also a result of credit holidays and liquidity support provided by governments to businesses. Nor has 
there been a run on banks, which is one of the most important threats to financial stability during any financial crisis.

Credit risk has become the most important danger for financial stability and the banking sector's capacity to finance the real economy. Its measurable reflection is the level of Non-Performing Loans (NPLs) and the dynamics of CoR. The main source of the erosion of banks' results is now to be found in loan write-offs, and their decapitalization seems to be an uppermost determinant of future lending, without which the recovery from the pandemic crisis will be difficult or at least long-lasting. Banks' performance is affected by a "search for yield" (risk management hypothesis) or "gamble to survive" policy. Alhalabi et al. (2021) provided important implications suggesting that in the case of large banks the risk management hypothesis was proved for the period preceding the subprime crisis. At the same time, the moral hazard behaviour related to excessive lending to risky borrowers who pay higher premiums thus substantially increasing credit risk was observed before the Global Financial Crisis, although it referred only to small banks. The post-crisis regulations contributed to the limitation of the "gamble to survive" behaviour of banks featuring poor financial performance.

The researches dedicated to NPLs, CoR or credit risk management are conducted from the perspective of either individual banks or banking sectors. Additionally, one can distinguish the approaches focusing on either macro- or microeconomic factors affecting the quality of credit portfolios.

So far, research on NPLs and the cost of risk has mainly focused on the determinants of their volatility in relation to individual banking sectors. Fratzscher et al. (2016) using a panel of 50 advanced and emerging market economies found that after the Global Financial Crisis, higher capital buffers improved aggregate bank stability (also in terms of assets quality), whereas strengthening of supervisory independence contributed to the reduction of the decline in domestic credit and improved the stability of banks. Kuzucu and Kuzucu (2019) examined determinants of NPLs in emerging countries compared to advanced countries during pre- and post-global financial crisis. Their results indicate that real GDP growth is the main determinant that affects the NPL ratio. They also found that the FX rate and FDI became statistically significant for emerging countries after the crisis period. Koju et al. (2020) examined credit risk in developed countries and found that the development of industrial and export-oriented sectors is the main driver of loan performance. These authors suggest also the adoption of an expansionary fiscal policy to increase GDP per capita and productivity in the aforementioned industries which then positively affects the stability of banking systems. Kjosevski and Petkovski (2017) analysed the relations between macroeconomic and bank-specific determinants of NPLs in the Baltic States. They proved that the most important macroeconomic factors affecting the NPL ratio are GDP growth, inflation and volume of domestic credit granted to the private sector. As regards bank-specific factors, they found that the most important ones were: the equity/total assets ratio, ROE, ROA and growth of gross loans. Mazreku et al. (2018) analysed the influence of macroeconomic factors on the level of NPL in transition countries. Their findings show that GDP growth and inflation are both negatively and significantly correlated with the level of NPLs, while the relation between unemployment and bad loans is positive. Mitrasevic and Bardarova (2020) pointed out the significant impact of weak lending standards and macroeconomic factors on the quality of loan portfolios. Ozili (2019) evidenced that the loan loss coverage ratio is positively associated with NPLs. His research allows stating that NPLs are negatively correlated with regulatory capital and bank liquidity. This implies that banking sectors equipped with greater regulatory capital and liquidity experience lower levels of NPLs. 
As mentioned, the problem of NPLs and CoR can be analysed from the perspective of individual banks to identify their specific features affecting credit portfolio quality. Analysing commercial banks listed on the Pakistan Stock Exchange over the period of 20052017 Khan et al. (2020) found that the operating efficiency and profitability indicators had a statistically significant negative association with NPLs. Using the econometric panel model, Borsuk (2017) concluded that GDP dynamics, unemployment rate and short-term interest rates had a significant impact on the level of cost of risk in Polish banks. Additionally, Hada et al. (2020) using linear regression showed that all selected independent variables (exchange rates, unemployment and inflation rates) had an important impact on the NPL of Romanian banks. RON-CHF exchange rate turned out to be the main factor affecting an increase in the NPL. Lawrence et al. (2020) concluded that NPL, CAR, LR, LTDR and age of banks had a significant and greater impact on the ROA of small banks compared to the big ones. At the same time, NPL ratio affected the ROE of small banks to a relatively lower extent than it did in the case of big credit institutions. An increase in NPLs can be an important obstacle to achieve assumed targets of monetary policy. Based on the data of 521 European banks, Thornton and di Thornton and Tomasso (2020) were able to conclude that there is a significant positive interaction of NPLs and capital as well as NPLs and profitability on the supply of bank credit. They also found that a bank's capital and profitability are key factors determining the answer to the question of whether NPLs impede the monetary policy transmission mechanism.

In comparison, relatively few studies have been devoted to the problem of NPLs during the COVID-19 pandemic. An increase in non-performing loans, deterioration of the quality of the loan portfolio and possible extreme cases of bank runs are mentioned as the main negative consequences of COVID-19 for banks (Goodell 2020). The banks most affected by the crisis are those with portfolios composed mainly of exposures to these economic sectors that were severely hit by the pandemic (hospitality, retail trade and transport sectors). Additionally, banks exposed to less vulnerable sectors may be challenged by the fallout from COVID-19. It refers especially to ones that entered the crisis with high levels of NPL (ECB —European Central Bank 2020). Kosztowniak (2020) examined the impact of changes in market conditions, the financial standing of enterprises and banks' capital requirements on the quality of the corporate loan portfolio in the Polish banking sector before and during COVID-19 and confirmed the pro-cyclical nature of the lending activity. Lelissa (2020) focused on private banking in Ethiopia. Among the measures to improve asset quality during COVID-19, he stressed the importance of setting the minimum provision level. Ari et al. (2020) emphasised that dealing with NPLs is critical to economic recovery and comparing the COVID-19 crisis to the 2008 Global Financial Crisis, nowadays, some factors are conducive to NPL resolution, i.e., higher capital adequacy ratios and the forward-looking IFRS 9 aiming at earlier NPL recognition. What is also crucial, the COVID-19 crisis was not preceded by a credit boom. Among the factors that could make NPL resolution a challenge, one shall mention higher government indebtedness, lower banks' profitability as well as weakness of institutional clients' balance sheets.

\section{Methodology}

The research was conducted on a sample of 13 commercial banks operating in Poland (Table 1). As of 31 December 2019, their total assets represent $84.90 \%$ of the assets of the banking sector in Poland (KNF-Polish Financial Supervision Authority 2020). 
Table 1. List of commercial banks analysed in the study.

\begin{tabular}{c}
\hline Name of the Bank (Alphabetical Order) \\
Alior Bank S.A. \\
Bank Handlowy w Warszawie S.A. \\
Bank Millennium S.A. \\
Bank Ochrony Środowiska S.A. \\
Bank Pocztowy S.A. \\
Bank Polska Kasa Opieki S.A. \\
BNP Paribas Bank Polska S.A. \\
Getin Noble Bank S.A. \\
Idea Bank S.A. \\
ING Bank Sląski S.A. \\
mBank S.A. \\
Towszechna Oszczędności Bank Polski S.A. \\
Santander Bank Polska SA \\
\hline
\end{tabular}

CoR was calculated according to the following formula:

CoR $=$ Loan Loss Provisions of the period analysed $/$ Average loans volume in the analysed period

The first step was to analyse the structural differentiation of the banks under consideration using the Czekanowski method (Sołtysiak and Jaskulski 1999). It allowed us to isolate groups of banks with similar behaviour of the CoR during the pandemic. This method makes it possible to perform a comparative analysis on a set consisting of $\mathrm{m}$ spatial elements $(p=1, \ldots, \mathrm{m})$ in terms of a structure built of $\mathrm{k}$ components $(i=1, \ldots, \mathrm{k})$ (Kukuła 2003,p. 51). The information on the structures in each spatial object forms a matrix:

$$
\left[\alpha_{i p}\right]=\left[\begin{array}{cccc}
\alpha_{11} & \alpha_{12} & \ldots & \alpha_{1 m} \\
\alpha_{21} & \alpha_{22} & \ldots & \alpha_{2 m} \\
\ldots & \ldots & \ldots & \ldots \\
\alpha_{k 1} & \alpha_{k 2} & \ldots & \alpha_{k m}
\end{array}\right]
$$

elements of which comply with the following conditions:: $0 \leq \alpha_{i p} \leq 1$ and $\sum_{i=1}^{k} \alpha_{i p}=1$. The estimation of the degree of differentiation of any pair of objects from

$$
\frac{m(m-1)}{2}
$$

possible pairwise combinations are enabled by the following:

$$
v_{p q}=\frac{\sum_{i=1}^{k}\left|\alpha_{i p-} \alpha_{i q}\right|}{2}, p, q=1,2, \ldots, m .
$$

The diversity measure takes normalized values belonging to the interval [0,1]. For a pair of objects with identical structures, it takes the value 0 , and for increasing structural differences it assumes growing values tending towards 1 . The values obtained in this way form a matrix of differentiation of structures:

$$
\left[v_{p q}\right]=\left[\begin{array}{cccc}
0 & v_{12} & \ldots & v_{1 m} \\
v_{21} & 0 & \ldots & v_{2 m} \\
\ldots & \ldots & \ldots & \ldots \\
v_{m 1} & v_{m 2} & \ldots & 0
\end{array}\right]
$$


It is a symmetric matrix in which the elements lying on the main diagonal take the value 0 . The threshold value of variation $v^{*}$ was taken as the arithmetic mean of the matrix elements:

$$
v^{*}=\bar{v}=\frac{2 \sum_{p=1}^{m} \sum_{q>p} v_{p q}}{m(m-1)},
$$

Pairs of objects showing less variation than the $v^{*}$ value can be considered similar (these boxes are circled). Czekanowski's diagram was then rearranged by moving rows and columns so that the circled boxes were as close as possible to the main diagonal.

In the second part of the analysis in order to specify the determinants of the observed tendencies in the formation of the dynamics of CoR the following models were used:

$$
D C o R=\beta 0+\beta 1 T C R+\beta 2 R O E+\beta 3 I M P+\beta 4 P R O V+\beta 5 D C R E D+\beta 6 D L L P+\phi i+\varepsilon i
$$

where:

DCoR-dynamics of changes in CoR between Q3 2020 and Q42019,

TCR - total capital ratio as of the end of 2019,

ROE-return on equity as of the end of 2019,

$I M P$-impaired loans as of the end of 2019,

PROV_-provision coverage ratio as of the end of 2019,

DCRED — dynamics of loans granted in the period of 2017-2019,

$D L L P$ - dynamics of provisions for on-balance sheet receivables and off-balance sheet items during the period of 2017-2019,

$\phi i$ - unobservable individual effects,

ci-error term.

The choice of diagnostic features was guided by: (i) substantive analysis, i.e., the importance of the indicator in the assessment of the dynamics of CoR following a crisis situation and (ii) statistical analysis based on the appropriate level of variability. Table 2 provides some descriptive statistics of the above variables.

Table 2. List of commercial banks analysed in the study.

\begin{tabular}{ccccccc}
\hline Specification & TCR & ROE & IMP & PROV & DCRED & DLLP \\
\hline min & 0.0146 & -0.2389 & 0.0300 & 0.5380 & 0.5389 & 0.3511 \\
max & 0.2009 & 0.1180 & 0.2259 & 0.8000 & 1.4713 & 5.3688 \\
arithmetic mean & 0.1553 & 0.0300 & 0.0854 & 0.6702 & 1.0897 & 1.5094 \\
median & 0.1687 & 0.0720 & 0.0520 & 0.6670 & 1.0898 & 1.3351 \\
standard deviation & 0.0488 & 0.1218 & 0.0616 & 0.0935 & 0.2559 & 1.2262 \\
$\quad$ V(x) standard & 0.3141 & 4.0629 & 0.7206 & 0.1395 & 0.2348 & 0.8124 \\
variability coeff. & & & & & & \\
\hline
\end{tabular}

An assessment of collinearity of variables using Variance Inflation Factors (VIF) was carried out. The values obtained do not indicate a problem of collinearity of variables and give support the possibility of using all explanatory variables. Statistica ver. 13.3 software by StatSoft Polska was used for calculations.

\section{Results}

Figure 1 presents the evolution of CoR in selected banks in the analysed period. 


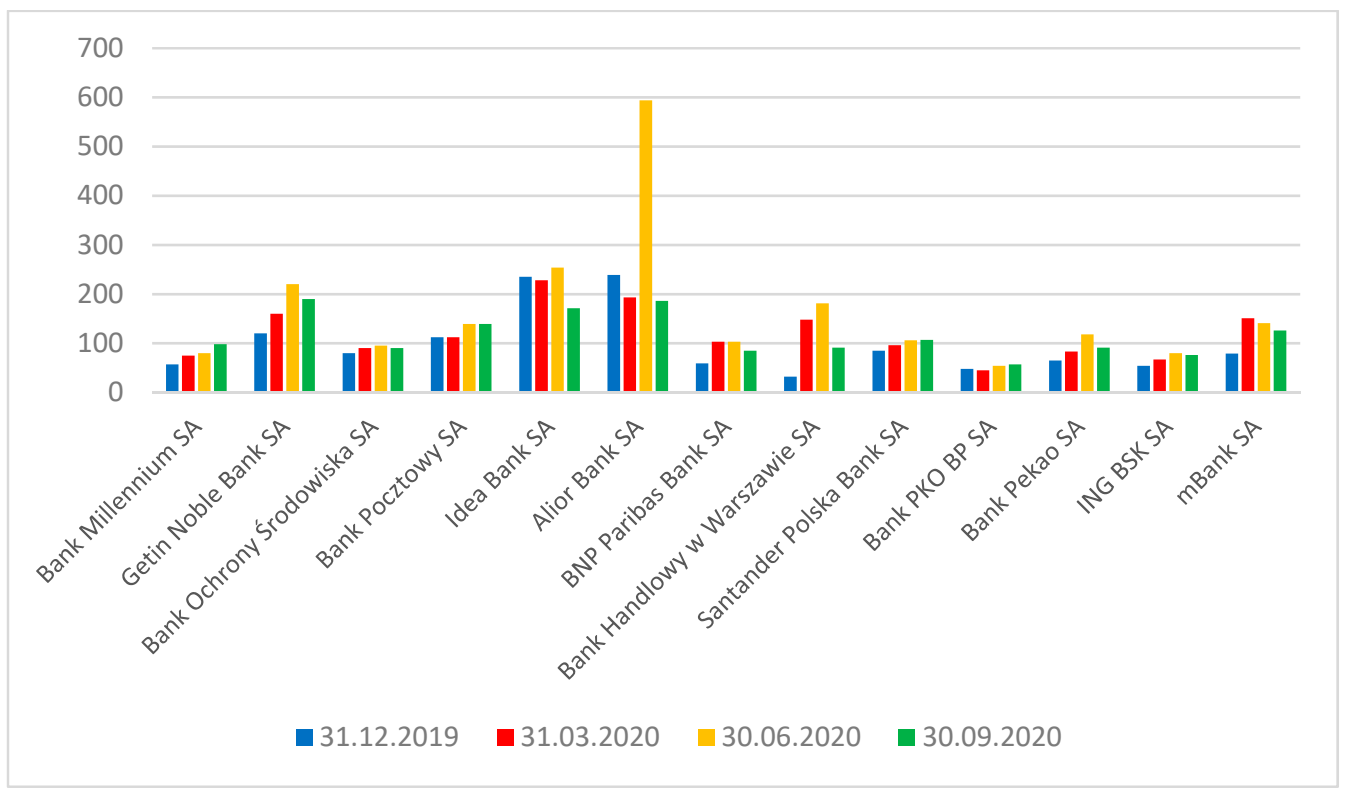

Figure 1. Cost of Risk (CoR) in the period of Q42019-Q3 2020.

The analysis of structural differentiation of the banks under consideration using the Czekanowski method identified five groups of banks depending on the development of the CoR (Figure 2).

Bank Ochrony Środowiska SA
Bank Pocztowy SA
BNP Paribas Bank Polska SA
Santander Bank Polska SA
PKO BP SA
ING BSK SA
Bank Millennium SA
Getin Noble Bank SA
Pekao SA
mBank SA
Idea Bank
Alior Bank
Bank Handlowy w Warszawie

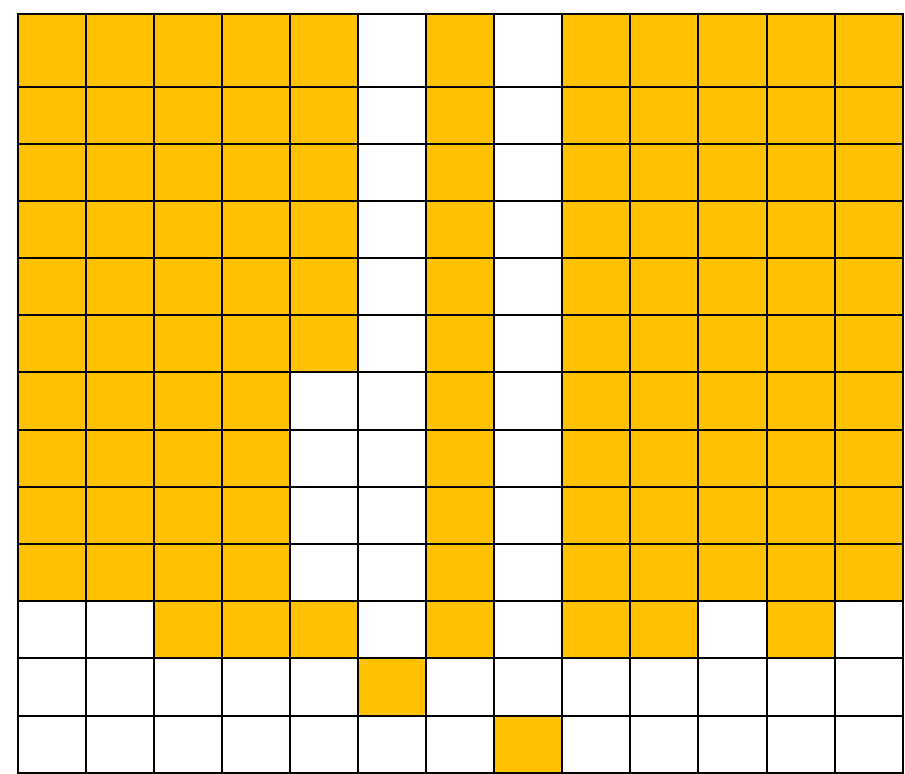

Figure 2. Bank groups according to the CoR evolution patterns.

The first group included: Bank Ochrony Środowiska SA, Bank Pocztowy SA, BNP Paribas Bank Polska SA, Santander Bank Polska SA, PKO BP SA and ING BSK SA. The second group, similar to the first one, covers: Bank Millennium SA, Getin Noble Bank SA, Pekao SA and mBank SA. Objects in these clusters are characterised by a systematic increase in the CoR over the period analysed. However, there is a noticeable tendency for the CoR to diminish in Q3 2020 relative to Q2 2020. The remaining banks: Idea Bank SA, Alior Bank SA and Bank Handlowy SA form separate groups that are not similar to the others.

The calculated values allow specifying the regression equation along with the estimation errors as presented in Table 3. 
Table 3. Estimation results.

\begin{tabular}{|c|c|c|c|c|c|c|}
\hline \multirow[t]{2}{*}{$N=13$} & \multicolumn{6}{|c|}{$\begin{array}{c}\text { Summary of the Regression of the Dependent Variable: DCoR } \\
R=0.96798274 R^{2}=0.93699058 \text { Corr. } R^{2}=0.86137928 \\
F(6,5)=12.392 p<0.00716 \text { Standard Error of Estimation: } 0.20185\end{array}$} \\
\hline & BETA & Stand. Err. BETA & B & Stand. Err. B & $t(5)$ & $p$ \\
\hline Intercept par. & & & 0.01823 & 0.965527 & 0.01888 & 0.985667 \\
\hline TCR & 0.67904 & 0.289334 & 7.23947 & 3.084696 & 2.34690 & 0.065813 \\
\hline ROE & -1.52940 & 0.341341 & -6.51754 & 1.454626 & -4.48056 & 0.006515 \\
\hline IMP & -1.03197 & 0.320846 & -8.71682 & 2.710126 & -3.21639 & 0.023560 \\
\hline PROV & 0.15834 & 0.120565 & 0.90346 & 0.687898 & 1.31336 & 0.246099 \\
\hline DCRED & 0.08194 & 0.137433 & 0.16629 & 0.278900 & 0.59622 & 0.576992 \\
\hline DLLP & 0.65612 & 0.127052 & 0.27993 & 0.054206 & 5.16417 & 0.003572 \\
\hline
\end{tabular}

The model parameters ROE, IMP and DLLP are material. There is a noticeable lack of significance of the coefficients for variables TCR, PROV and DCRED and the intercept parameter. Thus, the values of Student's t-statistic lead, at the significance level of 0.05, to the rejection of the hypothesis that the level of return on capital as of the end of 2019, the value of impaired loans as of the end of 2019 and the dynamics of impairment losses on financial assets and provisions for off-balance sheet liabilities during the period 2017-2019, do not affect the level of dynamics of the CoR in the period Q4 2019-Q3 2020. The opposite signs suggest that ROE and IMP variables affect the change in the dynamics of the CoR differently than DLLP-a growth of ROE and IMP pairs weakens the dynamics of CoR, while augmentation of the DLLP parameter contributes to an increase in the dynamics of the CoR in the analysed banks. The standard error of estimation amounting to 0.20185 is interpreted as the average deviation of the weight observed in the sample from the theoretical weight determined in the model. The value of the coefficient of determination R2 means that $93.70 \%$ of the total variation in the DCoR variable is explained by the model.

\section{Discussion}

The banks' first reaction to the pandemic crisis can be described as tightening of credit policy combined with a proactive increase in write-offs to cover potential losses. This was confirmed by the findings of a study conducted by Kulinska-Sadłocha et al. (2020). The pandemic time seems to be suitable to review procedures dedicated to credit risk assessment which was confirmed by Becker et al. (2020) who found that the ability to classify corporate borrowers by credit quality is greater during bad times and worse during good times. Their results confirmed that information frictions in corporate credit markets are intrinsically countercyclical and their presence justifies countercyclical buffers in banks to smooth credit cycles. Better credit risk identification as a result of intensified monitoring of corporate exposures and corporate liquidity support were the most important determinants of the relatively low growth of provisions and scale of asset reclassifications in Q3 2020. The additional write-offs that arose at that time were mainly related to the forecasted deterioration of macroeconomic parameters and a rising likelihood of legal risks materialising as a result of defective and abusive provisions in loan agreements concluded many years before the pandemic (the risk of judgments by the Court of Justice of the European Union, or CJEU). The behaviour of banks belonging to groups 1 and 2 confirms the above conclusions. The situation of banks that have formed separate groups needs further clarification.

In the case of Idea Bank SA, the cost of credit risk dynamically dropped in the analysed pandemic period. However, this was due to the fact that the bank had been in financial difficulties for several years. The bank was generating losses and breaching the capital adequacy required ratios. As a result, the Bank Guarantee Fund (a Polish institution guaranteeing deposits and carrying out recovery and resolution actions for credit institutions) finally issued a decision to initiate a compulsory restructuring of this bank as of 30 December 2020. The reasons for this were that: (i) there are premises that the entity will not comply with the operating conditions to such an extent that the authorisation to establish 
the bank may be revoked; (ii) the entity's assets are insufficient to meet its liabilities or there are indications that the entity's assets will not be sufficient to meet its liabilities.

The separate classification of Alior Bank SA resulted primarily from a significant increase in the bank's cost of risk in Q2 2020. It was related to the creation of additional provisions and write-offs in connection with COVID-19 in the amount of PLN 418 million, out of which PLN 269.8 million resulted from changes in model parameters, and PLN 148.2 million from individual write-offs. Additionally, Alior Bank SA estimated the impact of the CJEU ruling on the refund of part of the commission in the case of early repayment of consumer loans at PLN 192.1 million. Furthermore, it recognised a write-off on goodwill arising from the acquisition of Meritum Bank ICB SA in the amount of PLN 64.4 million. The incident was a one-off occurrence. As a consequence, the bank's ROE was $-15.8 \%$ in Q2 2020 (vs. 2.9\% in Q2 2019).

Bank Handlowy SA, on the other hand, was characterized by the highest dynamics of specific provisions created in the last three years (2017-2019) among all banks under consideration. Moreover, in that period it was characterised by the highest variability of write-offs. This bank created an additional provision of approx. PLN 137 million dedicated to the impact of the COVID-19 outbreak in Q2. This caused the CoR to more than quintuple in 1H 2020, to then halve in Q3 2020. The balance of provisions (result on expected credit losses of financial assets and provisions for contingent liabilities) was positive in Q3 (positive impact) and amounted to PLN 25.3 million. The bank stated that in the case of institutional banking, the main reason for the reversal of the provisions for expected credit losses was the reduction of exposure classified to the stage 3 portfolio.

Although since the beginning of the pandemic, which in Poland occurred in March 2020, dynamic growth of the CoR has been observed, its level at the end of September 2020 does not give cause for concern so far. It should be assumed, however, that the process of increasing the cost of risk will not slow down, despite the introduction of proactive write-off rules based on IFRS 9. This results from difficulties in the objective assessment of credit risk as the picture of borrowers' condition are obscured by government liquidity support, which is likely to be reduced in the upcoming months.

Despite the introduction of new standards for the classification of receivables and creation of write-offs in the Polish banking sector, in accordance with IFRS 9, aimed at immediate recognition of assets with increased risk, such an augmentation of risk in relation to specific exposures was observed to a relatively small extent. The high credit growth in 2017-2019, the likely reduction of state aid to companies and individuals in 2021, the prolonged period of the pandemic and the emergence of permanent changes in consumption patterns will probably all contribute to additional write-offs. This time there will be individualized provisions and probably totally much higher than in 2020. Again, therefore, the write-offs will be delayed. This conclusion corresponds with numerous research findings. For example, the research conducted by Laeven and Majnoni (2003) proved that banks delayed provisioning for bad loans until too late, when the cyclical downturns had already set in. This in turn magnified the impact of the economic cycle on banks' income and capital. A similar conclusion can be drawn from the research conducted by Reinders et al. (2020) who pointed out that the severe economic impact of the pandemic can threaten financial stability. However, there is a challenge to assess its gravity because banks' loss provisions are sluggish.

The identified correlations between (i) pre-pandemic ROE and CoR dynamics and the share of NPLs at the end of 2019 and CoR (negative correlations); (ii) pre-pandemic NPL dynamics and CoR dynamics (positive correlation), respectively, support the conclusion of two models of commercial banking in Poland. The first of them concerns large and mediumsized banks with good economic and financial conditions and low funding, which conduct a conservative credit and provisions policy. Due to the liquidity support for bank customers, no particular rationale for a significant increase in write-offs in relation to specific exposures arose. The second business model is for small banks with low profitability, low levels of regulatory capital and a high cost of funding. 
These banks are forced to seek out higher-risk customers, where the pandemic has become an additional factor in undermining an already limited ability to service the obligations. These clients were most often, because of their pre-pandemic status, excluded from public assistance. This conclusion corresponds with the findings of Ciukaj and Kil (2020), who verified the quality of credit exposure determinants of EU banks with a high level of impaired loans and found both macroeconomic and microeconomic factors. The authors noted that small banks with high dynamics of new loans and a low return on assets are characterized by a relatively high level of NPL.

\section{Conclusions}

The study allowed us to draw the following conclusions:

- The higher the rate of return on capital in the pre-pandemic period, the more cautious was the credit risk policy of commercial banks. This resulted in a relatively lower growth rate of the CoR during the first quarters of the pandemic.

- In the case of banks with a relatively low share of impaired loans as of the end of 2019, the fastest growth of the CoR was found. The above should be associated with a change in the parameters of credit risk models resulting in a decrease in the recovery rate from collateral and expected cash flows. The second factor is the adoption of a more conservative approach to the classification of receivables under IFRS 9, which was also a result of the auditors' policy.

- The dynamics of write-offs in the three years preceding the pandemic crisis is positively correlated with the dynamics of the CoR in the pandemic period. This should be associated with two distinct credit policy models observed in Polish commercial banking.

In conclusion, 2020 was the year in which state aid had a largely positive impact on the ability of bank customers to meet their obligations. Assuming that after the pandemic period, the customers' standing returns to pre-COVID-19 levels, banks did not significantly reclassify their exposures. The cost of risk has increased due to general provisions related to the update of macroeconomic forecasts. Another important reason for the risk growth was the write-offs for potential losses resulting from court proceedings, which had been prompted by the recent CJEU rulings on consumer and mortgage loans, unfavourable for banks. In view of the above, the cost of risk may increase within the current year and in the following years (when the public aid is discontinued). It will therefore be interesting to repeat this research in the future.

The presented analysis has several limitations that may affect the final results obtained in the study. First, the number of banks under consideration is relatively small. However, the study took into account the majority of commercial banks that operate in Poland (assets of the banks analysed account for $84.90 \%$ of the assets of the banking sector in Poland) as well as some other studies based on relatively small samples, in fact, limited to commercial banks constituting specific banking sectors which is also the case of our research (Hada et al. 2020; Lawrence et al. 2020). The second limitation is connected with the relatively short horizon of the study. However, the intention was to analyse the evolution of the cost of credit risk at banks immediately after the outbreak of the pandemic and the application of support to businesses and individuals. Nevertheless, the conclusions of this study and future similar ones may be useful for managers of audit firms and supervisory authorities. Another targeted group of stakeholders potentially interested in the result of our research is bank managers. CoR determinants (predictors) seem to be important drivers for credit risk policy as well as for planning future P\&L statements. In addition, CoR determinants should support the process of review and verification of the current internal credit rating procedures in terms of their adequacy to the increased credit risk driven by the pandemic.

Author Contributions: Conceptualization, Z.K. and P.N.; methodology, Z.K. and P.N.; software, Z.K. and P.N.; validation, Z.K. and P.N.; formal analysis, Z.K. and P.N.; investigation, Z.K. and P.N.; 
resources, Z.K. and P.N.; data curation, Z.K. and P.N.; writing-original draft preparation, Z.K. and P.N.; writing-review and editing, Z.K. and P.N.; visualization, Z.K. and P.N.; supervision, Z.K. and P.N.; project administration, Z.K. and P.N.; funding acquisition, Z.K. and P.N. All authors have read and agreed to the published version of the manuscript.

Funding: This research received no external funding.

Institutional Review Board Statement: Not applicable.

Informed Consent Statement: Not applicable.

Data Availability Statement: Not applicable.

Acknowledgments: We wish to thank anonymous referees for valuable comments and suggestions.

Conflicts of Interest: The authors declare no conflict of interest.

\section{References}

Alhalabi, Thaer, Vitor Castro, and Justine Wood. 2021. The relationship between excessive lending, risk premium and risk-taking: Evidence from European banks. International Journal of Finance \& Economics. Unpulished Work. [CrossRef]

Ari, Anil, Sophia Chen, and Lev Ratnovski. 2020. COVID-19 and Non-Performing Loans: Lessons from Past Crises. Available online: https: / / ssrn.com/abstract=3632272 (accessed on 28 November 2020).

Becker, Bo, Marieke Bos, and Kasper Roszbach. 2020. Bad Times, Good Credit. Journal of Money Credit and Banking 10: 107-42. [CrossRef]

Bitar, Mohammad, and Amine Tarazi. 2020. A Note on Regulatory Responses to COVID-19 Pandemic: Balancing Banks' Solvency and Contribution to Recovery. Available online: https:/ / ssrn.com/abstract=3631131 (accessed on 28 November 2020).

Borio, Claudio. 2020. The prudential response to the COVID-19 Crisis. Speech by Claudio Borio Head of the Monetary and Economic Department on the Occasion of the Bank's Annual General Meeting in Basel on 30 June 2020. Available online: https:/ / www.bis.org/speeches/sp200630a.pdf (accessed on 30 December 2020).

Borsuk, Marcin. 2017. Wpływ czynników makroekonomicznych na poziom kosztów ryzyka kredytowego banków. Studia i Prace Kolegium Zarządzania i Finansów 153: 49-62.

Cecchetti, Stephen G., and Kermit L. Schoenholtz. 2020. Contagion: Bank runs and COVID-19. In Economics in the Time of COVID-19. Edited by Richard Baldwin and Beatrice Weber di Mauro. London: CEPR Press, pp. 77-80.

Ciukaj, Radosław, and Krzysztof Kil. 2020. Determinants of the non-performing loan ratio in the European Union banking sectors with a high level of impaired loans. Economics and Business Review 6: 22-45. [CrossRef]

Demirguc-Kunt, Asli, Alvaro Pedraza, and Claudia Ruiz-Ortega. 2020. Banking Sector Performance during the COVID-19 Crisis. Policy Research Working Paper Series. No. 9363. Washington, DC: World Bank. Available online: https://openknowledge.worldbank. org/handle/10986/34369 (accessed on 28 November 2020).

ECB_European Central Bank. 2020. COVID-19: The Impact on Europe's Smaller Banks. Available online: https://www. bankingsupervision.europa.eu/press/publications/newsletter/2020/html/ssm.nl201118_1.en.html (accessed on 20 January 2021).

Fratzscher, Marcel, Philipp Johann König, and Claudia Lambert. 2016. Credit provision and banking stability after the Great Financial Crisis: The role of bank regulation and the quality of governance. Journal of International Money and Finance 66: 113-35. [CrossRef]

Goodell, John W. 2020. COVID-19 and finance: Agendas for future research. Finance Research Letters 35: 101512. [CrossRef] [PubMed]

Hada, Teodor, Nicoleta Bărbuță-Mișu, Iulia C. Iuga, and Dorian Wainberg. 2020. Macroeconomic Determinants of Nonperforming Loans of Romanian Banks. Sustainability 12: 7533. [CrossRef]

Khan, Muhammad, Asima Siddique, and Zahid Sarwar. 2020. Determinants of non-performing loans in the banking sector in developing state. Asian Journal of Accounting Research 5: 135-45. [CrossRef]

Kjosevski, Jordan, and Mihail Petkovski. 2017. Non-performing loans in Baltic States: Determinants and macroeconomic effects. Baltic Journal of Economics 17: 25-44. [CrossRef]

KNF-Polish Financial Supervision Authority. 2020. Banking Sector-Monthly Data, Urząd Komisji Nadzoru Finansowego: Warsaw. Available online: https://www.knf.gov.pl/en/REPORTS_AND_ANALYSIS/Banking/Monthly_data (accessed on 21 December 2018).

Koju, Laxmi, Ram Koju, and Shouyang Wang. 2020. Macroeconomic determinants of credit risks: Evidence from high-income countries. European Journal of Management and Business Economics 1: 41-53. [CrossRef]

Korzeb, Zbigniew, and Paweł Niedziółka. 2020. Resistance of commercial banks to the crisis caused by the COVID-19 pandemic: the case of Poland. Equilibrium Quarterly Journal of Economics and Economic Policy 15: 205-34. [CrossRef]

Kosztowniak, Aneta. 2020. Changes in the quality of the loan portfolios in the Polish banking system. Economics Business and Organization Research. Paper presented at the Third Economics, Business and Organization Research (EBOR) Conference, Rome, November 2020; pp. 33-49. Available online: https://dergipark.org.tr/en/pub/ebor/issue/58610/847677 (accessed on 20 January 2021).

Kukuła, Karol. 2003. Elementy Statystyki w Zadaniach. Warsaw: Wydawnictwo Naukowe PWN. 
Kulińska-Sadłocha, Ewa, Monika Marcinkowska, and Jan Szambelańczyk. 2020. The impact of pandemic risk on the activity of banks based on the Polish banking sector in the face of COVID-19. Safe Bank 2: 31-59.

Kuzucu, Narman, and Serpil Kuzucu. 2019. What Drives Non-Performing Loans? Evidence from Emerging and Advanced Economies during Pre- and Post-Global Financial Crisis. Emerging Markets Finance and Trade 55: 1694-708. [CrossRef]

Laeven, Luc, and Giovanni Majnoni. 2003. Loan loss provisioning and economic slowdowns: Too much, too late. Journal of Financial Intermediation 12: 178-97. [CrossRef]

Lawrence, Babatunde, Mishelle Doorasamy, and Prince Sarpong. 2020. The Impact of Credit Risk on Performance: A Case of South African Commercial Banks. Global Business Review 11. [CrossRef]

Lelissa, Tesfaye. 2020. The Impact of COVID-19 on the Ethiopian Private Banking System. Available online: https://ssrn.com/ abstract $=3624944$ (accessed on 28 November 2020).

Li, Lei, Philip E. Strahan, and Song Zhang. 2020. Banks as lenders of first resort: Evidence from the COVID-19 crisis. The Review of Corporate Finance Studies 9: 472-500. [CrossRef]

Mazreku, Ibish, Fisnik Morina, Valdrin Misiri Jonathan V. Spiteri, and Simon Grima. 2018. Determinants of the level of non-performing loans in commercial banks of transition countries. European Research Studies Journal 21: 3-13. [CrossRef]

Mitrasevic, Mirela, and Snezana Bardarova. 2020. Causes of non-payment of mortgage loans: Theoretical and practical aspects. UTMS Journal of Economics 11: 138-50.

Naili, Maryem, and Younes Lahrichi. 2020. The determinants of banks' credit risk: Review of the literature and future research agenda. International Journal of Finance $\mathcal{E}$ Economics 8. [CrossRef]

Ozili, Peterson K. 2019. Non-performing loans and financial development: New evidence. Journal of Risk Finance 20: 59-81. [CrossRef]

Reinders, Henk Jan, Dirk Schoenmaker Dirk, and Mathijs A. Van Dijk. 2020. Is COVID-19 a Threat to Financial Stability in Europe? CEPR Discussion Paper. DP14922. Available online: https:/ /ssrn.com/abstract=3638026 (accessed on 28 November 2020).

Sołtysiak, Arkadiusz, and Piotr Jaskulski. 1999. Czekanowski's diagram. A method of multidimensional clustering. In New Techniques for Old Times. CAA 98. Computer Applications and Quantitative Methods in Archaeology. Proceedings of the 26th Conference, Barcelona, March 1998. Oxford: Archaeopress, pp. 175-84.

Thornton, John, and Caterina di Tomasso. 2020. The effect of non-performing loans on credit expansion: Do capital and profitability matter? Evidence from European banks. International Journal of Finance E Economics 8. [CrossRef]

$\mathrm{Wu}$, Desheng, and David L. Olson. 2020. The Effect of COVID-19 on the Banking Sector. In Pandemic Risk Management in Operations and Finance. Computational Risk Management. Edited by Desheng Wu and David L. Olson. Cham: Springer, pp. 89-99. 